\title{
Maja Maksimović, Joanna Ostrouch-Kamińska, Katarina Popović, Aleksandar Bulajić (red.), Contemporary Issues and Perspectives on Gender Research in Adult Education, University of Belgrade, Belgrad 2016, ss. 281
}

Recenzowana książka, której tytuł można przetłumaczyć jako „Współczesne kwestie i perspektywy badań nad płcią w edukacji dorosłych”, jest kolejnym głosem w dyskusji nad problematyką różnic płci w edukacji dorosłych i wpisuje się w cykl wydawniczy prac będących pokłosiem naukowych debat odbywających się w ramach European Society for Research on the Education of Adults (ESREA). Redaktorki i redaktor naukowy tomu: Maja Maksimović, Joanna Ostrouch-Kamińska, Katarina Popović i Aleksandar Bulajić, opatrzyli go wstępem przybliżającym przewodnie wątki, nadające kształt książce. Artykuły składające się na publikację obejmują aspekty filozoficzne, historyczne, teoretyczne, empiryczne, a także praktyczne problematyki różnic płci w andragogice, co niewątpliwie stanowi wartość monografii. Tym samym książka wypełnia lukę w feministycznym dyskursie w edukacji dorosłych. Warto podkreślić, że autorki i autorzy poszczególnych rozdziałów nie tylko podjęli się próby analizy wielu wątków dotyczących tej problematyki, ale również ukazali przestrzenie stosowania różnych podejść metodologicznych i praktyk edukacyjnych w zakresie analizowanego zagadnienia.

Książka składa się z wprowadzenia i 17 rozdziałów, które składają się na pięć części. Pierwszą część zatytułowaną Filozofia, historia, płeć (gender) otwiera artykuł Agnieszki Zemburzuskiej. Prowadzona przez autorkę polemika koncentruje się wokół pytania, w jaki sposób różne tradycje filozoficzne i perspektywa różnic płci wpłynęły na dyskurs w teorii i praktyce edukacji dorosłych, w kontekście politycznych i ekonomicznych przemian, jakie nastąpiły w Polsce w ostatnim ćwierćwieczu. Drugi rozdział napisany przez Natašę Vujisić Živković i Katarinę Popović ukazuje z kolei dziewiętnastowieczną Serbię jako egzemplifikację wglądu w różne społeczne i ideologiczne 
paradygmaty związane z odbywającą się w tamtym czasie modernizacją i jej wpływem na politykę edukacji dziewcząt i kobiety w Serbii.

Druga część omawianej książki prezentuje wyniki badań nad różnicami płci. Rozdział autorstwa Maji Maksimović i Aleksandara Bulajiča koncentruje się na metodologicznych i filozoficznych aspektach transformacyjnych i ukrytych procesach uczenia się podmiotów uczestniczących w sztuce teatralnej The Red. Sztuka ta traktuje o osobistej tragedii i transformacji kobiet, których intymność reguluje dominujący dyskurs. Kolejny rozdział autorstwa Zoricy Miloševicia i Snezany Medic to analiza prac promocyjnych studentek i studentów pod kątem sposobów wykorzystywania problematyki płci, częstotliwości jej poruszania w programie studiów oraz wskazań do włączania tej tematyki w edukację dorosłych.

Trzecią część książki, zatytułowaną Płeć, akademia, władza, otwiera artykuł Cristiny C. Vieiry i Marii Jorge Ferro. Autorki prezentują wyniki badań mówiące o tym, iż takie kwestie jak: płeć biologiczna, płeć społeczno-kulturowa, feminizm, męskość, relacje władzy, wydają się pomijane w konstruktach studentek i studentów. W związku z tym rekomendują potrzebę większego akcentowania i wprowadzania tej problematyki do programu studiów. Marie-Pierre Moreau podejmuje się próby bliższego zrozumienia różnych przestrzeni, w których spotykają się zobowiązania studentów rodziców w dialogu płci. Wyniki ukazują, w jaki sposób tradycyjne role płciowe są podtrzymywane lub, przeciwnie, wychodzą poza ten podział. Rozdział siódmy prezentuje analizę badań empirycznych prowadzonych przez Aleksandrę Pejatović i Violetę Orlovic Lovren. Autorki przybliżają układ władz dziekańskich na wydziałach uczelni państwowych i prywatnych w Serbii, przyjmując jako kryterium analizy płeć. Badaczki przyglądają się, na ile tradycyjny podział pracy zachowany jest w pozycjach prodziekanów. Kolejne badania dotyczące problematyki płci w kontekście akademickim opisane zostały w ósmym rozdziale autorstwa Jeleny Đermanov, Marijany Kosanovic i Jeleny Vukicevic. Badaczki przybliżają różnorodne formy praktyk dyskryminacyjnych, których doświadczyły badane przez nie studentki w toku studiowania. Nataša Simić i Vesna Đorđević prezentują badania przeprowadzone wśród 90 badaczek z Serbii. Rozmówczynie wskazały kilka czynników związanych z płcią, które mają wpływ na ich satysfakcję z pracy oraz na konieczność zmian w ustawodawstwie serbskim. Zwróciły również uwagę na potrzebę bycia bardziej uznanym w naukowym świecie oraz w szerszym kontekście społecznym.

Czwartą część książki zatytułowaną Rozpoznawanie męskości otwiera artykuł prezentujący badania Joanny Ostrouch-Kamińskiej oraz Iwony 
Chmury-Rutkowskiej. Autorki przybliżają analizy ukazujące sferę relacji dorosłych mężczyzn i ich starzejących się rodziców. Analizie poddają kluczowe elementy konstytuujące te relacje, umieszczając je w kontekście funkcjonowania współczesnych rodzin, patriarchalnego modelu rodziny oraz socjalizacji mężczyzn zmierzającej do niezależności. Barry Golding, autor kolejnego rozdziału, prezentuje obszary związane z uczeniem się starszych mężczyzn i ich samopoczuciem w związku z przebywaniem we wspólnocie Men's Sheds. Przybliżona w artykule krytyczna analiza nad tym zjawiskiem, oparta na postulatach feministycznej epistemologii, pokazuje, jak proces uczenia się mężczyzn nabiera nowego kształtu, wychodząc poza tradycyjne ramy postrzegania i rozumienia męskości. Dwunasty rozdział autorstwa Christine Buchwald to analiza przemocy seksualnej występującej w czasie II wojny światowej widzianej oczami mężczyzn. Autorka wyjaśnia, dlaczego mówienie o przemocy seksualnej występującej w czasie wojny jest trudne oraz jak i dlaczego edukacja dorosłych może i powinna interweniować w obszary (post-)konfliktu.

Ostatnią część książki zatytułowaną Płeć (gender) w praktyce edukacji dorostych otwiera artykuł Tamary Nikolic Maksić i Nikoli Koruga. Tekst ma na celu wyjaśnienie różnic między dorosłymi kobietami i mężczyznami w zakresie ich uczestnictwa w kształceniu do czasu wolnego. Unikając prostych generalizacji oraz sądów wartościujących, autorki ukazują bardziej złożony i szerszy pogląd na relację pomiędzy płcią a edukacją do czasu wolnego, prezentując rekomendacje udoskonalające metodologię, politykę oraz praktykę analizowanego obszaru. Kolejny rozdział napisany przez Elisabeth Sander, Martinę Endepohls-Ulpe i Claudię Quaiser-Pohl jest krytycznym spojrzeniem na programy i strategie edukacji dorosłych w naukach technicznych oraz w matematyce w Niemczech. Autorki przyglądają się lukom, jakie występują w tym obszarze ze względu na płeć, jak również analizują inicjatywy wspierające i motywujące kobiety do robienia kariery w tych obszarach. Alzira Manuel i Oleg Popow są autorami rozdziału, który jest opisem badań przeprowadzonych wśród uczestników pozaformalnej edukacji zawodowej i szkoleń zawodowych w Mozambiku. Badania ukazują różnice płciowe w korzyściach, jakie uczestnicy czerpią z tej edukacji, odzwierciedlając tradycyjną, męską i kobiecą dychotomię ról. Przedostatni rozdział autorstwa Marii Ivanovej i Anety Dimitrovej przedstawia badania na temat preferowanych metod uczenia się starszych kobiet i mężczyzn w Bułgarii. Artykuł prezentuje krótki przegląd obecnej sytuacji w dziedzinie kształcenia ustawicznego w tym kraju oraz integracji społecznej osób w podeszłym wieku, odnosząc się do zasad i zaleceń europejskich. Książkę zamyka rozdział Antoniety Ro- 
chy i Teresy Cardoso. Jest to artykuł o charakterze badawczym, który ukazuje analizę udziału portugalskich kobiet $\mathrm{w}$ (poza)formalnej edukacji dorosłych, $z$ uwzględnieniem możliwości tworzenia im przestrzeni do tego, aby osiągnęły swoje cele zarówno zawodowe, jak i życiowe.

Recenzowana książka zawiera bogaty i wieloaspektowy przegląd badań nad zagadnieniem różnic płci w edukacji dorosłych. W tworzeniu publikacji uczestniczyło 33 autorów i autorek z Europy i Australii, którzy ukazywali podejmowaną problematykę w kontekście zarówno lokalnym, jak i globalnym, co niezwykle wzbogaciło rozważania będące tematem omawianego opracowania. Książka jest świetnym przyczynkiem do dyskusji nad wykorzystywaniem feministycznej epistemologii w edukacji dorosłych, a także zachętą do dalszych rozważań, dyskusji, badań i działań nad analizowanym zagadnieniem. Publikacja ta może stanowić źródło wiedzy nie tylko dla badaczy, teoretyków, ale także praktyków - osób zaangażowanych w edukację dorosłych. Jest to godna polecenia praca, w której autorkom i autorom udało się spojrzeć na analizowane zagadnienie w sposób nowatorski i inspirujący do dalszych eksploracji. Recenzowana pozycja została wydana w formie e-booka, w wolnym dostępie pod adresem: http://aesrs.webs.com/ ESREA\%20eBook.pdf. 